\title{
Sağlık Kurumlarında Çalışanların Kurumda Kalma ya da Ayrılma Kararlarının Belirlenmesinde Örgütsel Bağlılığın Etkisi: İzmir İlinde Bir Araştırma
}

\author{
Suna AKÇA $\mathbf{A}^{1}$
}

\section{Nevzat DEVEBAKAN 2}

$\ddot{o} z$

Să̆lık hizmetlerinde hastalara güvenli ve kaliteli sağlık hizmeti sunmak kadar să̆glk hizmet sunucularının örgütsel bağlllıkları da o kadar önemlidir. Daha verimli ve performansı yüksek çalışmayı amaç edinen sağlık kurum ve kuruluşları, çalışanlarının örgütsel bağlılıklarını artırmak ve kurumdan ayrılmaları önlemek için çeşitli politikalar geliştirmek zorundadırlar. Bu çalışma İzmir'de bulunan bir kamu diş merkezinde săglık çalışanlarının örgütsel bağglılıkları ve kurumdan ayrılma eğilimleri arasındaki ilişkiyi test etmek için yapılmıştır. Araştırma konularının arasındaki ilişkiyi test etmek için Allen ve Mayer tarafindan geliştirilen "Örgütsel Bă̆lılık Ölçeği”" kullanılmıştır. Çalışanların kurumdan ayrlma niyetlerinin olup olmadĭ̆ sorulmuş ve veriler "evet" veya "hayır" cevapları üzerinden toplanmıştır. Araştırma sonuçlarl; să̆lık çalışanlarının örgütsel bağlllıklarının düzeylerinin düşük olduğuna, örgütsel bağlllık faktörleri arasında pozitif bir ilişkinin mevcut olduğuna ve kurumdan ayrılma düzeyleri ile negatif orantı gösterdiğine işaret etmektedir.

Anahtar Kelimeler: Să̆lık Kurumları, Örgütsel Bă̆lılık, İşten Ayrılma.

JEL Sinıflandırma Kodları: I19, M19 .

The Impact of Organizational Commitment of Healthcare Workers in Determining Their Decision to Remain In the Institution or Leave: A Research in the Province of Izmir

\begin{abstract}
It's essential to provide patients with safe and high quality health care service, thus the health care professionals' commitment to organization is a very important. Health care organizations which aim to provide more efficient and high performance work must develop various policies to improve the commitments of their employees and reduce employee leave the organization. In this study health care organizations and classifications, commitment of health care employees and the relationship of resign have been tested. To assess this, organizational commitment survey described by Allen and Mayer was used. Employees were asked if they had intentions to leave the job and the data were collected via "yes" or "no" answers. According to results of this study, the commitment of health care employees was found to be low. As a result, there is a negative correlation between organizational commitment factors and resign incidence.
\end{abstract}

Keywords: Health Care Organizations, Organizational Commitment, Leave the Job.

JEL Classification Codes: I19, M19.

\footnotetext{
${ }^{1}$ Alsancak Ağız ve Diş Sağlığı Merkezi, Hemşire, Hastane ve Sağlık Kurumları Yönetimi Bilim Uzmanı, suna-akca@hotmail.com

${ }^{2}$ Yrd. Doç. Dr., Dokuz Eylül Üniversitesi, İzmir Meslek Yüksekokulu Sağlık Kurumları İşletmeciliği, nevzatd@deu.edu.tr
} 


\section{GİRIŞ}

S.AKÇA -N.DEVEBAKAN

Sağlık sektörü ve başta hastaneler olmak üzere sağlık hizmet sunucuları hizmetler sektörü içinde önemli bir yere sahiptir. Hizmetler sektöründe, hizmeti bizzat sunan sağlık profesyonellerinin tutum ve davranışlarının sunulan hizmetlerin kalitesi üzerinde birincil derecede etkili olacağı muhakkaktır. Söz konusu gereklilik sağlık kurumlarında çalışan odaklı yönetim anlayışının önemini artırmaktadır. Günümüzde sürekli değişen çevresel koşullar karşısında rekabet üstünlügünün elde edilmesi ve sürdürülmesinde örgütlerin; dinamik ve proaktif olmaları, takım odakl1, etkili, yenilikçi ve öğrenen örgüt olmaları yönünde baskılar giderek artmaktadır. Bu nedenle klasik yönetiminin tam tersi olan modern yönetim anlayışı olan Toplam Kalite Yönetimi’ni benimsemiş sağlık kurumları yöneticilerinin hastalar kadar, çalışanları için de ellerinden gelenin en iyisini yapması neredeyse bir zorunluluk haline gelmiştir. Günümüzün sağlık kurumları yöneticilerinden beklenen rol; maliyet temelli ve rekabetçi bir ortamda gerek kamu gerekse de özel sektör sağllk kurumlarında çalışanlarına odaklanmasıdır. Sağlık kurumlarının yöneticilerinin çalışanları ile odaklanacağı konulardan bir tanesi de; çalışanlarının örgütsel bağl11ık düzeylerini arttırmak ve kurumda kalmaları için çaba harcamalarıdır. $\mathrm{Bu}$ çalışmada öncelikle örgütsel bağlığın kavramsal temellerini ve sağlık kurumlarında örgütsel bağl1lık ve kurumdan ayrılma ilişkisine yönelik literatüre yer verilecektir. Çalışmanın ilerleyen kısımlarında ilgili literatür ışında hazırlanan hipotezlere yer verilecek olup, arkasından sağlık kurumlarında çalışanların kurumda kalma ya da ayrılma kararlarının belirlenmesinde örgütsel bağlılığın etkisini ölçemeye yönelik İzmir ilinde yapılan bir araştırmaya yer verilecektir.

\section{2. ÖRGÜTSEL BAĞLILIĞIN KAVRAMSAL TEMELLERİ}

Konu ile ilgili literatüre bakıldığında örgütsel bağl1lığın disiplinler arası bir konu olması, farklı alanlardaki araştırmacıların ilgi alanına girmesi ve her araştırmacının kavrama kendi bakış açısı ile yaklaşmasından dolayı üzerinde görüş birliği sağlanamadığı görülmektedir. Bu alanda yapılan çalışmalara en önemli katkıyı sağladığı düşünülen Meyer ve Allen ilk olarak 1984 yılında iki boyutlu bir ölçek hazırlamışlardır. Araştırmacıların ilk hazırladıkları ölçek duygusal bağlılık ve 
devam bağlılı̆̆1 kavramlarını içermekteydi (Meyer and Allen, 1984; 374). Daha sonradan modele eklenen zorunlu (normatif) bağl1lı̆g1 ekleyip örgütsel bağlılığın devam, duygusal ve normatif olmak üzere üç boyutunun olduğunu öne sürmüşlerdir. Buna göre devam bağl1lığ 1 , çalışanların örgütten ayrılmalarının işletmeye getireceği maliyeti ve olumsuzlukları dikkate alması, bir zorunluluk olarak işletmeye devam etmesi olarak tanımlanırken, duygusal bağllık, işletmede çalışan bireylerin duygusal olarak kendi tercihleri ile işletmede kalma arzusunu ifade etmektedir. Yazarlara göre normatif bağlılık ise, çalışanların ahlaki bir görev duygusuyla ve işletmeden ayrılmamanın gereğine inandıkları için kendilerini örgüte bağlı hissetmeleri şeklinde tanımlanmıştır (Meyer and Allen, 1997:11).

Örgütsel bağlılık, çalışanın örgüte olan psikolojik yaklaşımını ifade eden, çalışan ile örgüt arasındaki ilişkiyi yansıtan, örgüt üyeliğini devam ettirme kararına yol açan psikolojik bir durumdur (Allen ve Meyer, 1990: 14). Allen ve Meyer, duygusal bağl11ık, devam bağl11 $\breve{g ̆}_{1}$ ve normatif bağl1lığı birer bağl1lık kategorisine dâhil etmek yerine, bu kategorilerin bir kombinasyonu olarak düşünülmesi gerektiğini öne sürmektedir. Sonuç itibariyle bir iş görenin örgütle ilişkisi bu üç bağl1lık türünün farklı düzeylerini içerebilmektedir. Örneğin, bir çalışan örgüte yüksek düzeyde bağl1lık hissederken, örgütte kalmayı sürdürmek için zorunluluk hissedebilir; bir başka çalışan örgüt için çalışmaktan zevk duyarken, örgütten ayrılmanın ekonomik açıdan getireceklerini göze almayabilir (Çakar ve Demircan, 2005: 55). Özetle duygusal bağl1lık, kişiler istedikleri için, devamlılık bağ l1lığ1 çıkarlar bağlanmayı gerektirdiği için ve normatif bağlılık ise, ahlaki gerekçelerle ortaya çıkmaktadır (Wasti, 2002). Yine Becker ve arkadaşları örgütsel bağlılığı çalışanın işyerine psikolojik olarak bağlanması olarak tanımlamıştır (Becker vd., 1996 :464).

Örgütsel bağl1lık literatürü, araştırmacıların büyük ölçüde iş görenlerin bağl1lık niteliği, kişinin örgütsel amaç ve çıkarları koruma isteği, örgüte dönük belli davranışsal gerekleri yerine getirme ve örgütle paylaşılan birlikteliğin daha çok moral-psikolojik gücü üzerinde odaklandıklarını göstermektedir. Bunun yanında yazarlardan önemli bir bölümü de örgütsel bağlılığı, iş görenlerin, örgütün farklı 


\section{S.AKÇA -N.DEVEBAKAN}

parçalarına veya öğelerine bağlılığı şeklinde ilişkilendirmişlerdir (Balay, 2004: 1618) .

Etzioni örgütsel bağlılığı, çalışanların örgüte bağl1lıkları bakımından üçe ayırmaktadır. Buna göre en olumsuz uçta negatif-yabancılaştırıcı, ortada nötrhesapçı ve en olumlu uçta ise pozitif-moral bağlılık vardır. Söz konusu örgütsel bağl1lık, ahlaki bağl1lık, hesapçı bağlılık ve yabancılaştırıcı bağlılık olarak sıralanmaktadır (Çetin, 2004: 94). Başka bir yaklaşımda örgütsel bağlılık; çalışanların örgüte olan bağlarının gücü olarak tanımlanmaktadır (Wahn, 1998). O'Reilly ve Chatman, Örgütsel bağl1lığ1, iş görenin örgütü için hissettiği psikolojik bağ olarak tanımlamaktadır (O’Reilly ve Chatman, 1986).

Örgütsel bağl11ık için diğer sınıflandırmalardan farklı bir bakış açısı Argyris (1998) tarafından yapılmıştır. Bu bakış açısı bağlılı̆̆ı, ekonomi, strateji, finansal yönetim gibi örgütsel uygulamaların temelini oluşturan bir faktör olarak açıklamaktadır. Bağlılık, örgüt için çalışanları harekete geçiren bir güç olarak değerlendirilmekte ve bağlılık olmadan örgütsel girişimin veya düşüncelerin uygulanamayacağı öne sürülmektedir.

Güçlü duygusal bağl1lık, bireylerin örgütte kalma ve örgütün amaç ve değerlerini kabullenmesi anlamına gelmektedir (İnce ve Gül, 2005:40). Duygusal bağl1lı̆̆ yüksek olan çalışanlar, ekonomik nedenleri göz ardı ederek, sadece örgütün temsil ettiği değerleri uygun buldukları ve onun misyonunu gerçekleştirmesine yardımcı olmayı istedikleri için örgütlerinde kalmak istemektedirler. $\mathrm{Bu}$ durumda örgütün performans1 ön planda olup, birey örgüt başarısını veya zararını kendisininmiş gibi kabullenmektedir (Baysal ve Paksoy, 1999:227).

Devam bağl1lığ1 ise, bir iş görenin örgütte çalıştığ 1 süre içerisinde harcadığ 1 emek, zaman ve çaba ile edindiği statü, para gibi kazanımlarını örgütten ayrılmasıyla birlikte, kaybedeceği düşüncesiyle oluşan bağl11ıktır (Yalçın ve İplik, 2005: 398). Normatif bağlılık ise, örgütsel bağl1lığın ahlaki boyutunu ifade eder. Kişinin örgütte çalışmayı kendisi için bir görev olarak görmesi ve örgütüne bağl1lık 
göstermenin doğru olduğunu hissetmesi olup, örgütten ayrılma sonucunda ortaya çıkacak kayıpların hesaplanmasından etkilenmektedir. Başka bir ifade ile Normatif bağl1lık, örgütte kalmaya yönelik algılanan zorunluluğa odaklanmaktadır (Özutku, 2008:80).

Örgütsel bağl1lık, çalışanların kurumda kalma ya da ayrılma eğiliminin en önemli belirleyicilerinden birisi olduğundan, bağlılık yaratma insan kaynakları yönetiminin temelini oluşturur (Duygulu ve Abaan, 2007: 61). Rusbult ve arkadaşları kurumdan ayrılma niyetini, çalışanların iş koşullarından tatminsiz olmaları durumunda göstermiş oldukları yıkıcı ve aktif eylemlerdir şeklinde tanımlamaktadırlar (Rusbult vd, 1988). Çalışmanın bundan sonraki kısmında sağlık kurumları/sağlık çalışanları açısından örgütsel bağl1lık-kurumdan ayrılma ilişkisine yönelik literatüre yer verilecektir.

\section{SAĞLIK KURUMLARINDA ÖRGÜTSEL BAĞLILIK VE} KURUMDAN AYRILMA

Örgütsel bağl1lığın en güçlü ve en fazla beklenen sonucu, kurumdan ayrılma niyetinin ve dolayısıyla işgücü devrinin azalmasıdır (Sabuncuoğlu, 2007: 617). Örgüte bağlılığın düşük olmasının, örgütlerde verimlilik sorunları, iş doyumsuzluğu, işe devamsızlık, işe geç gelme, kurumdan ayrılma gibi olumsuz durumlara neden olduğu belirtilmekte ve bu nedenle de çalışanın kurumdan ayrılma davranışını ve beklenmedik durumları önceden tahmin etmede çalışanların örgütsel bağlılıklarına bakıldığı bilinmektedir (Sergül ve Korkmaz, 2008:11).

Sağl1k sektöründe sağlık çalışanlarının örgüte bağlılı̆̆ını sağlamak için, kurumun çalışana birtakım imkânlar sunması gereklidir. Bu imkânları başta iş doyumu olmak üzere, tatmin edici ücret, terfi imkânları, profesyonel biri olarak değerlendirilmek, yeterli personel sayısıyla çalışmak ve güvenli bir iş çevresi şeklinde sıralayabiliriz. Sağlık çalışanlarının örgütsel bağlılıklarının hasta memnuniyeti ve sağlık hizmetlerinin kalitesi üzerinde olumlu bir etkisi olabilir.

Sağl1k sektöründe, sağlık personelinin örgütsel amaç ve değerleri içselleştirmesi ve örgütle bütünleşmesi anlamına gelen örgütsel bağlılı̆̆ın sağlanması; çalışanların 


\section{S.AKÇA -N.DEVEBAKAN}

yaptıkları işe ve işyerlerine iyi duygular beslemesi anlamına gelen iş tatmini düzeylerinin yükseltilmesi ve kurumdan ayrılma niyetlerinin azaltılması önemli bir faktör haline gelmiştir (Gül vd, 2008: 7). Türkiye'de Ankara'da hemşireler yapılan üzerinde yapılan bir araştırmada mesleğe bağlılık ile örgüte devamlılık bağl1lı̆g 1 ve normatif bağl1lık, işe bağl1lık ve aileye bağl1lık arasında anlamlı, pozitif yönlü bir ilişki bulunduğu belirlenmiştir. Araştırmacılar bu durumun hemşirelerin gerek eğitimleri gerekse çalışma yaşamları boyunca mesleğe bağl11ıklarını sağlayacak ve artıracak uygulamaların, onların örgütlerine karşı normatif ve devamlılık bağlılıklarını, işlerine ve ailelerine karşı bağl1lıklarını da artıracağını öne sürmektedir (Benligiray ve Sönmez, 2011:36)

Gider ve arkadaşları tarafından 3 hastanede ve 483 hemşire ve tıbbi sekreterler üzerinde yapılan bir araştırmada İş doyumu ve örgütsel bağlılık arasında güçlü ve pozitif yönlü bir ilişki saptanmıştır (Gider vd., 2011:9). Afyon Kocatepe Üniversitesi Hastanesi’nde farklı birimlerde çalışan 249 hekim üzerinde yapılan bir araştırmada benzer şekilde hekimlerin örgütsel bağl1lık düzeyleri ile iş doyumları arasında doğru bir orantı tespit edilmiştir (Karahan, 2009: 421). Sağlık çalışanlarının mevcut işini bırakmada kolayca yeni bir iş bulma potansiyelinin etkili olduğu söylenebilir. Nitekim Ankara'da yapılan bir araştırmada uzman hekimlerde örgütsel bağlılığın pratisyenlere göre daha düşük çıkması; uzmanların çalıştıkları hastanelerin dışında başka kurum ve alanlarda da kolayca iş bulabilmeleriyle ilişkilendirilmiştir (Çetin vd., 2014:11).

Sağl1k kurumlarında çalışanların örgütsel bağl1lıklarının ölçülmesi yöneticilerine önemli veriler sağlayacaktır. Buradan elde edilen ipuçları sayesinde yöneticiler, yönetsel modellerini tekrar gözden geçirme fırsatını yakalayacaklardır. Selçuk Üniversitesi Meram Tıp Fakültesi Hastanesinde yapılan araştırma sonucunda uzun süredir hastanede görev yapan hemşirelerin kurumlarına bağlılık düzeylerinin düşük olduğu ortaya çıkmıştır. Diğer bir anlatımla hemşireler aidiyetlerinin göreli olarak düşük olduğu söylenebilir. İlgili çalışmada doktorların hemşirelere göre kuruma daha bağlı olduklarını saptanmıştır. Araştırmacılara göre bunun nedeninin 10 yıl ve daha fazla süredir bu hastanede çalışan doktorların 
kendilerini kısmen hastanede "aileden birisi gibi" hissetmeleridir (Sevinç ve Şahin, 2012: 279)

Türkiye'de Cumhuriyet Üniversitesi Hastanesi'nde hemşireler üzerinde yapılan bir araştırmada; hemşirelerin en güçlü örgütsel bağlık kaynağının; kurumlarının başarısı için normalden daha fazla çaba harcamaya hazır olduklarıdır (Demirel vd., 2014:92). Aynı araştırmada katılımcıların kurumun geleceğinden endişe etmesi ise; en zayıf örgütsel bağlılık kriteri olarak saptanmıştır. Gülhane Askeri Tıp Akademisi'nde yapılan bir çalışmada ise; İş tatmini üzerinde "duygusal bağlılı̆̆ın" ve normatif bağlılığın" anlamlı ve pozitif yönde bir etkisinin olduğu, buna karşın “devamlılık Bağlılığı”nın iş tatmini üzerinde anlamlı bir etkisinin olmadığı tespit edilmiştir (Çelen vd, 2013:399).

İzmir de bir tıp fakültesi hastanesinin merkez laboratuarı çalışanları üzerinde, örgütsel bağlılık ve kurumdan ayrılma niyeti arasındaki ilişkiyi tespit etmeye yönelik yapılan bir çalışmada; duygusal bağlılı̆̆ın çalışanların kurumdan ayrılma niyetlerini en çok, normatif bağl1lığın ise en az etkileyen değişken olduğu tespit saptanmıştır. İlgili çalışmada örgüsel bağılık düzeylerinin kurumdan ayrılma niyetini negatif yönde etkilediği de tespit edilmiştir (Uyguç ve Çımrın, 2004: 96).

Bingöl'de yapılan bir araştırmada, eğitim düzeyi ve gelir düzeyi yüksek olan hekimlerin ve yardımcı sağlık personelinin, genel örgütsel bağlılık düzeyi ile örgütsel bağl1lık boyut düzeylerinin diğer gruplardan düşük çıkmasının nedenlerinden birinin hekimlerin ve yardımcı sağlı personellerinin büyük kısmının Bingöl doğumlu olmaması ile ilişkilendirilmiştir (Tekingündüz ve Tengilimoğlu, 2013: 95). Bu anlamda sosyo-ekonomik çevrenin de örgütsel bağl1lık düzeyini etkilediği söylenebilir.

İzmir'de üç ayrı hastanenin acil servislerinde yapılan bir çalışmada acil Servislerde hasta bakım ve tedavi hizmeti veren sağlık çalışanlarının örgütsel bağl1lık düzeylerinin düşük olduğu görülmektedir. (Yavuz vd, 2014:111). Tokat Devlet Hastanesinde yapılan bir araştırmada; iş tatmini ve örgütsel bağlılı̆̆ın 


\section{S.AKÇA -N.DEVEBAKAN}

kurumdan ayrılma niyetini negatif yönde, performansı ise pozitif yönde etkilediği bulgusuna ulaşılmıştır (Gül ve Oktay, 2008: 1).

Konya'da sağlık bakanlığına bağlı devlet hastanelerinde yapılan bir çalışmada ise, kurumdan ayrılma niyeti ve işe devamsızlık arasında pozitif yönlü ve istatistiksel bakımdan anlamlı ilişki tespit edilmiştir (Çelik vd, 2014:159). İstanbul'da Türkiye Cumhuriyeti Sağlık Bakanlığına bağlı İstanbul'daki beş eğitim ve araştırma hastanesinde yapılan bir araştırmada hekimlerin ve hemşirelerin örgütsel bağl1lık ve örgütsel güven seviyeleri arttıkça iş doyumu seviyelerinin de arttığı tespit edilmiştir (Top, 2012: 258). Manisa Salihli'de yapılan bir çalışmada çalışanların örgüte duygusal bağılıklarının düşük, devam bağlılığı ve normatif bağlılık düzeyinin orta düzeyde tespit edilmiştir. $\mathrm{Bu}$ sonuç sağlık çalışanlarının cazip alternatifler bulduğu anda işi terk edecekleri şeklinde yorumlanabilir (Tetik, 2012: 284).

Afyonkarahisar Devlet Hastanesinde farklı unvanlara sahip toplam 321 sağlik çalışanı üzerinde yapılan bir çalışmada liderlik ile örgütsel bağlılık arasında anlamlı ilişkilerin olduğu, liderliğin, çalışanların örgütsel bağlılığını olumlu yönde etkilediği saptanmıştır (Karahan, 2008:145). Hastane yöneticileri, çalışanlarına daha fazla kişisel ilgi gösterdikleri ve onların özel sorunlarıyla ilgilendikleri takdirde bu onların kurumlarına olan bağlılıklarını artıracaktır (Erdem, 2007: 75). İlgili literatür ışığında araştırmanın hipotezleri aşağıdaki gibi tespit edilmiş ve sıralanmıştır;

- H1: Çalışanlarının duygusal bağl1lık, devam bağl1lı̆̆ ve normatif bağl1lık faktörleri, cinsiyete göre farklılık gösterir.

- H2: Çalışanlarının duygusal bağl1lık, devam bağl1lı̆̆ ve normatif bağl1lık faktörleri, eğitim durumlarına göre farklılık gösterir.

- H3: Çalışanlarının duygusal bağl1lık, devam bağ $\operatorname{ll}_{1} \mathrm{~g}_{1}$ ve normatif bağl1lık faktörleri arasında istatistiksel olarak anlamlı bir ilişki vardır.

- H4: Çalışanlarının kurumdan ayrılma kararlarının dağılımı cinsiyete göre farkl111k gösterir. 
- H5: Çalışanlarının örgütsel bağlılılığı kurumdan ayrılma kararına göre farkl111k gösterir.

Çalışmamızın bundan sonraki kısımlarında sağlık çalışanlarının örgütsel bağl1lıkları ve kurumdan ayrılma eğilimleri arasındaki ilişkiyi test etmek için İzmir ilindeki kamuya ait bir diş merkezinde yapılan bir araştırmaya yer verilecektir.

\section{ARAŞTIRMA METODOLOJISİ}

\subsection{Amaç}

$\mathrm{Bu}$ araştırmanın amacı sağlık hizmetlerinde çalışan personelin örgütsel bağlılık (duygusal bağl11ık, devamlılık bağl11 l̆ğ1 ve normatif bağl11ık) ve örgütten ayrılma niyeti arasındaki ilişkilerini ne yönde etkilediğini ortaya çıkarmak ve örgütten ayrılma niyetini belirlemektir. Araştırma T.C. Sağlık Bakanlı̆̆ı'na bağlı İzmir ilinde faaliyet gösteren Ağız ve Diş Sağlı̆̆ Merkezi (ADSM) çalışanlarına yönelik, örgütsel bağl11ık ile kurumdan ayrılma arasındaki etkileşim analiz edilmiştir.

\subsection{Kapsam ve Sinırlılıklar}

$\mathrm{Bu}$ araştırma İzmir ilinde faaliyet gösteren kamuya bağlı ADSM'inde, 657 sayılı devlet memurları kanununa göre çalışan kadrolu ve 4/B' li personeli kapsamaktadır. ADSM 80 diş üniti kapasitesine sahip, entegre klinikleri, ameliyathane, ortodonti kliniği, pedodonti kliniği, engelli kliniği, sterilizasyon ünitesi ve acil servis alanlarında hizmet veren bir merkezdir. Araştırmaya dış kaynak yoluyla hizmet alınan bilgi işlem, temizlik, yemek ve güvenlik firması ve çalışanları, hizmet satın alımı söz konusu olduğundan ve kurum ile karşılıklı bir sözleşme imzalanmamasından dolayı araştırma kapsamına dahil edilmemiştir. $\mathrm{Bu}$ çalışanlar taşeron firma elemanı olarak adlandırılmakta ve doğrudan sağlık hizmeti sunumunda rol almamaktadırlar. $\mathrm{Bu}$ sebepten dolayı araştırmaya dâhil edilmemiştir.

\subsection{Evren ve Örneklem}

Araştırmanın evrenini 2013 yılında ADSM'inde fiili olarak çalışan 150 personel oluşturmaktadır. Araştırmada tam sayım yapılarak tüm personele ulaşılmıştır. Elde 


\section{S.AKÇA -N.DEVEBAKAN}

edilen verilerden 45 tanesi eksik ya da hatalı doldurma nedeniyle analizlere dahil edilmemiş ve toplam 105 katılımcı üzerinden analizler yapılmıştır. Belirli evrenler için kabul edilebilir örnek büyüklüğüne göre örneklem sayısı yeterli kabul edilmiştir.

\subsection{Veri Toplama Gereçleri}

Araştırmada ADSM çalışanlarının örgütsel bağlılık düzeylerinin ölçülmesinde Meyer ve Allen (1991) tarafından geliştirilen ve Türkçe'ye uyarlaması Baysal ve Paksoy (1999) tarafından yapılan “Örgütsel Bağlılık Ölçeği” kullanılmıştır. Ölçeğin ilk kısmında sosyo-demografik sorulara, ikinci kısmında ise kurum çalışanlarının örgütsel bağlılıklarını ölçmek amacıyla oluşturulmuş olan 5 noktalı likert tipi 20 soruya (Kesinlikle Katılmıyorum=1; Kesinlikle Katıllyorum=5) yer verilmiştir. Ölçeğin 1, 2, 3, 4, 5, 6 ve 7'inci soruları duygusal bağl1lık, $8,9,10,11,12$ ve 13 'üncü soruları devam bağl1lığ1 ve $14,15,16,17,18,19$ ve 20 'inci soruları ise normatif bağlılık boyutuna ilişkin soru önermelerini içermektedir. Son olarak çalışanların kurumdan ayrılma kararlarının belirlenmesine yönelik olarak, “yakın zamanda kurumdan ayrılmayı düşünüyor musunuz?” sorusu (Evet-Hayır) sorulmuştur.

\subsection{Verilerin Analizi Yöntemi}

Araştırma verileri SPSS 18.0 programı ile analiz edilmiştir. Araştırmada ölçeğin güvenilirliği için güvenilirlik analizi, tanımsal istatistik analizleri için frekans analizi, bağımsız örneklem $\mathrm{t}$ testi, tek yönlü varyans analizi yapılmıştır. Ölçeğin güvenirliği için yapılan analizde alfa katsayısı 0,839 olarak hesaplanmıştır. Allen ve Meyer tarafından geliştirilen ölçek için faktör analizi yapılmıştır. Duygusal bağl1lık, devam bağl1lığ1 ve normatif bağl11ık olmak üzere ölçek, üç faktör olarak analize tabii tutulmuştur. Örgütsel bağlılık ile kurumdan ayrılma kararlarları arasındaki ilişkinin tespiti ve örgütsel bağl1lık faktörleri arasındaki ilişkinin tespiti için korelasyon analizi yapılarak ilişki saptanmıştır. Anket verilerine ilişkin analiz yapılırken istatistiksel açıdan ilk önce verilerin parametrik olup olmadığına bakılmıştır. 
Dokuz Eylül Üniversitesi İktisadi ve İdari Bilimler Fakültesi Dergisi Cilt:32, Sayı:2, Yıl:2017, ss. 239-261

Verilerin normal dağılıma uygun olup olmadığı Shapiro-Wilks testiyle incelenmiştir. Test sonucuna göre her üç örgütsel bağl1l1k boyutu ve kurumdan ayrılma niyeti için $\mathrm{p}$ değeri 0.05 'ten büyük olduğu için örgütsel bağl1lık boyutlarının ve kurumdan ayrılma niyetinin normal dağılıma uygun olduğu tespit edilmiştir. $\mathrm{Bu}$ nedenle hipotezlerin test edilmesinde parametrik hipotez testleri kullanılmıştır. Örgütsel bağl1lık boyutlarının ve kurumdan ayrılma niyetinin çalışanların cinsiyetine göre farklılaşıp farklılaşmadığının test edilmesi için bağımsız örneklem $\mathrm{t}$ testi, eğitim düzeyine göre farklılaşıp farklılaşmadığının belirlenmesi içini Anova testi kullanılmıştır.

\section{BULGULAR}

Araştırmanın Sosyo-demografik bulguları ile tanımlayıcı istatistikler Tablo-1 de gösterilmektedir.

Tablo-1: Tanımlayıcı İstatistikler Tablosu

\begin{tabular}{|c|c|c|c|}
\hline \multicolumn{4}{|c|}{$\mathrm{N}=105$} \\
\hline \multirow{3}{*}{ Cinsiyet } & & Frekans & Yüzde \\
\hline & Kadın & 71 & 67,6 \\
\hline & Erkek & 34 & 32,4 \\
\hline \multirow{4}{*}{ Yaş } & 20-30 Yaş & 6 & 5,7 \\
\hline & 31-40 Yaş & 30 & 28,6 \\
\hline & 41-50 Yaş & 49 & 46,7 \\
\hline & 51 Yaş Üstü & 20 & 19 \\
\hline \multirow{5}{*}{ Meslek } & Diş Hekimi & 54 & 51,4 \\
\hline & Hemşire & 10 & 9,5 \\
\hline & Diş Teknisyeni & 16 & 15,2 \\
\hline & Röntgen Teknisyeni & 3 & 2,9 \\
\hline & İdari Personel & 21 & 20 \\
\hline
\end{tabular}


S.AKÇA -N.DEVEBAKAN

\begin{tabular}{|c|c|c|c|}
\hline & Teknik Personel & 1 & 1 \\
\hline \multirow{4}{*}{ Eğitim } & Lise & 12 & 11,4 \\
\hline & Ön lisans & 19 & 18,1 \\
\hline & Lisans & 43 & 41 \\
\hline & Yüksek Lisans & 31 & 29,5 \\
\hline \multirow{4}{*}{ Mesleki Yıl } & 5 Yildan Az & 8 & 7,6 \\
\hline & 6-10 Y1l & 8 & 7,6 \\
\hline & 11-15 Y1l & 12 & 11,4 \\
\hline & 16 Yıl üzeri & 77 & 73,3 \\
\hline \multirow{4}{*}{ Kurumda Çalışma Yılı } & 5 Yildan Az & 42 & 40 \\
\hline & 6-10 Y 11 & 10 & 9,5 \\
\hline & 11-15 Y1l & 14 & 13,3 \\
\hline & 16 Y1l üzeri & 39 & 37,1 \\
\hline \multirow{6}{*}{ Çalışılan Birim } & Klinik & 57 & 54,3 \\
\hline & Laboratuvar & 13 & 12,4 \\
\hline & Ameliyathane & 1 & 1 \\
\hline & Röntgen & 2 & 1,9 \\
\hline & Yönetsel İdari & 20 & 19 \\
\hline & Diğer & 12 & 11,4 \\
\hline \multirow{2}{*}{ İşten Ayrılma Kararı } & Evet & 45 & 42,9 \\
\hline & Hayır & 60 & 57,1 \\
\hline
\end{tabular}

Anketin örgütsel bağlllık anketi ölçeği 5'li Likert tipi ölçek üzerinden değerlendirildiği için boyut ortalamalarına bakıldığı zaman en düşük ortalamanın 3,19 puan ortalamasıyla normatif bağl1lı boyutunda olduğu, duygusal bağl1lık 
boyutunun 3,35, devam bağl1lığı boyutunun ise 3,43 olduğu görülmektedir. Evet, Hayır ifadesi şeklinde sorulan kurumdan ayrılmayı düşünüyor musunuz sorusuna ise katılımcıların \%42,9' unun evet cevabını, \%57,1' inin ise hayır cevab1 verdiği görülmektedir.

$\mathrm{Bu}$ çalışmada duygusal bağlılık boyutunda en yüksek puan ortalamasına sahip olan "Çalıştığım kurumdan, dışarıdaki insanlara gururla bahsediyorum" İfadesi 3,59 puan ortalamasına ve "Çalıştığım kurumun problemlerini kendi problemlerim gibi hissediyorum" ifadesi 3,50 ortalamaya sahiptir. Buna göre araştırmaya katılan çalışanlar orta düzeyde de olsa çalıştıkları kurumdan gururla bahsetmekte ve kurum sorunlarını kendi sorunları gibi algılamaktadırlar.

Devam bağl1lı̆g 1 boyutunda en yüksek puan ortalamasına sahip olan "Başka bir iş ayarlamadan bu kurumdan ayrıldığımda neler olacağ 1 konusunda endişe hissediyorum" İfadesi 3,57 ortalamaya sahiptir. Katılımcılar kurumdan ayrıldıkları zaman ne olacağı konusunda endişe yaşadıklarını belirtmişlerdir.

Genel ortalamalar içerisindeki en düşük ortalamaya sahip olan normatif bağl1l1k boyutunun en yüksek ortalaması "Benim için bu kurumdan ayrılmanın olumsuz sonuçlarından biri de var olan alternatiflerin azlı̆̆ıdır" ifadesi 3,36 ortalamaya sahiptir. Araştırmaya katılan çalışanlar kurumdan ayrıldıkları zaman tekrardan iş bulamama gibi bir korkuya sahiptirler. 2,93 ortalama ile araştırmaya katılan çalışanlar kuruma çok şey borçlu olduklarını düşünmekte ve 2,84 ortalama ile de kurumdan ayrıldıklarında suçluluk duygusu içine katılacakları yönünde fikir beyan etmişlerdir.

\section{HIPOTEZLERİNIN TEST EDİLMESI}

H1: ADSM çalışanlarının duygusal bağlılık, devam bağlılığı ve normatif bağlılık faktörleri, cinsiyete göre farklılık gösterir.

Örgütsel bağl1lık faktörlerinin cinsiyete göre farkl111k hipotezinin test etmek amacı ile verilere bağımsız örneklem t-testi uygulanmıştır. Cinsiyet grubuna yapılan t-testi sonucunda duygusal bağlılık ve normatif bağl1lık faktörlerinin \%95 güven aralığında işaret değeri $\mathrm{p}>0,05$ olduğundan anlamlı bir farkın olmadığ 1 


\section{S.AKÇA -N.DEVEBAKAN}

görülmektedir. Devam bağl1lı̆̆ faktörünün cinsiyete göre farklılığ1 analizinde $\mathrm{t}=2,407$ ve buna denk gelen işaret değeri $\mathrm{p}=0,018<0,05$ olduğundan hipotez kabul edilmiştir. Kadın katılımcılar 3,57 ortalama ile erkek katılımcılara göre 3,12 ortalama ile devam bağl1lıklarının daha yüksek olduğunu göstermektedir. H1 kabul edilmiştir. Konya'da hastanede çalışan hemşirelerin örgütsel bağlılık düzeyleri ile ilgili yapılan bir çalışmada ise; cinsiyet değişkeni ile örgütsel bağlılık düzeyleri arasında anlamlı bir farklılık tespit edilememiştir (Kaya, 2010: 91).

H2: ADSM çalışanlarının duygusal bağlılık, devam bağlılığı ve normatif bağlılık faktörleri, eğitim durumlarına göre farklılık gösterir.

Devam bağl1lığ1, duygusal bağl1lık ve normatif bağl1lık eğitim durumuna göre farkl11ık gösterir hipotezini test etmek için verilere Anova testi uygulanmıştır. Analiz sonucu örgütsel bağlılık faktörleri ile eğitim durumları arasında anlamlı farklılığın olmadığına işaret etmektedir $(\mathrm{F}=0,10, \mathrm{p}=0,96 ; \mathrm{F}=1,91, \mathrm{p}=0,13 ; \mathrm{F}=1,77$, $\mathrm{p}=0,16$ ). İlgili boyutlara ait istatistikî veriler sırasıyla belirtilmiştir.H2 kabul edilmiştir. Ancak literatürde benzer konuda Amerika'da hemşireler üzerinde yapılan bir araştırmada hemşirelerin örgütsel bağl1lık düzeyleri ile eğitim düzeyi arasında pozitif yönlü düşük bir ilişki saptanmıştır (Al-Hussami, 2008:291). Türkiye'de Salihli (Manisa) Devlet Hastanesi’nde çalışan sağlık elemanlarının çalıştıkları hastaneye olan bağlılık düzeylerini belirlemek için yapılan bir çalışmada örgütsel bağlılığın duygusal ve normatif bağlılık boyutları ile katılımcıların eğitim düzeyleri arasında istatistiksel olarak anlamlı bir farklılık bulunmamış ancak devam bağlılığı boyutu ile eğitim değişkeni arasında istatistiksel olarak anlamlı bir farklılık bulunmuştur. Sözü edilen çalışmada lise mezunlarının devam bağımlılığı, yüksek lisans mezunlarına göre daha yüksek bulunmuştur (Tetik, 2012:284). Konya'da hastanede çalışan hemşirelerin örgütsel bağlılık düzeyleri ile ilgili yapılan bir çalışmada ise; eğitim durumu ile örgütsel bağl11ı düzeyleri karşılaştırıldığında hiç bir farklılık tespit edilmemiştir (Kaya, 2010: 91).

H3: ADSM çalışanlarının duygusal bağlılık, devam bağlılı̆ğ ve normatif bağlılık faktörleri arasında istatistiksel olarak anlamı bir ilişki vardır. 
Korelasyon analizi sonucunda ADSM çalışanlarının örgütsel bağlılık faktörleri arasında orta düzeyde ve pozitif yönlü bir ilişki mevcuttur. Bu ilişkiler \%99 güvenle anlamlıdır. Duygusal bağll1ık ile normatif bağl1lık (Pearson Korelasyon= 0,482 ) arasında pozitif yönlü ve orta düzeyde bir ilişki vardır. Buna göre kurum çalışanlarının duygusal bağlılıklarının artması durumunda orta düzeyde normatif bağl1lıkları da artacaktır. ADSM çalışanlarının devam bağlılığı ve normatif bağlılık ilişkilerinde ise yine pozitif yönlü ve zayıf bir ilişki mevcuttur (Pearson Korelasyon= 0,255). Analiz çıktısına göre kurum çalışanların devam bağlılıkları arttığında azda olsa normatif bağlılıklarının da artacağı yönündedir.H3 kabul edilmiştir. $\mathrm{Bu}$ çalışmada devam bağlılığı en yüksek olarak saptanmıştır. Hastanelerde görev yapan sağlık çalışanlarının örgütsel bağl1lık düzeylerinin belirlenmesine yönelik Konya'da yapılan benzer bir çalışmada; devam bağlılı̆g 1 boyutunun normatif bağl1lık boyutundan yüksek çıkması ülkemizde alternatif iş imkânlarının kısıtlı olması ile ilişkilendirilmiştir (Özata, 2015:164). Bu anlamda çalışmamızın bulguları bu anlamda anılan çalışma bulguları ile paralellik göstermektedir. Yine Bingöl'de sağlık çalışanları üzerinde yapılan konu ile ilgili 516 sağlık çalışanı üzerinde yapılan bir araştırmada personelin duygusal bağlılık düzeyi 3.2, devam bağlılığı düzeyi 3.1 ve normatif bağl1lık düzeyi 3.0 olarak saptanmıştır (Tekingündüz ve Tengilimoğlu, 2013:

\section{H4: ADSM çalışanlarının kurumdan ayrıma kararlarının dağılımı} cinsiyete göre farklılık gösterir.

Çalışanların kurumdan ayrılma kararlarının dağılımının cinsiyet değişkeni açısından farklılık göstermesi Ki-kare analizi ile test edilmiştir. Analiz sonuçları Tablo-3'te gösterilmektedir. Yapılan analizde ki-kare katsayısı 1, 876 ve buna denk gelen işaret değeri $\mathrm{p}=0,321>0,05$ olduğundan cinsiyete göre kurumdan ayrilma kararının dağılımı farklılık göstermemektedir. Genelin \%42,9'u kurumdan ayrılma kararında olduğunu belirtmiş, erkelerde bu oran \% 40,85 ve kadınlarda \%47,06 olmasına rağmen ki-kare testinde bu farklılık anlamlı bulunmamıştır. Bu nedenle cinsiyete göre kurumdan ayrılma kararının dağılımının aynı olduğu söylenebilir. Dolayısı ile H4 ret edilmiştir. Literatürde cinsiyet gibi kişisel özelliklerin, örgüte 


\section{S.AKÇA -N.DEVEBAKAN}

bağl1lığa olan etkilerini inceleyen çalışmalarda, cinsiyetin örgütsel bağl1lıkla ilişkisi olduğuna yönelik araştırma sonuçlarının değişken olduğu görülmektedir (Duygulu ve Abaan, 2007:63).

Tablo-2: Kurumdan Ayrılma Kararının Cinayete Göre Dağıllımı ve Ki-Kare Analizi

\begin{tabular}{|c|c|c|c|c|c|c|c|}
\hline & \multicolumn{3}{|c|}{ Kurumdan Ayrılma Kararı } & \multirow{2}{*}{ Toplam } & \multirow{2}{*}{$\begin{array}{l}\text { Pearson } \\
\text { Ki-Kare }\end{array}$} & \multirow{2}{*}{$\begin{array}{l}\text { P İşaret } \\
\text { Değeri }\end{array}$} \\
\hline & & & Evet & Hayır & & & \\
\hline \multirow{4}{*}{ Cinsiyet } & \multirow[b]{2}{*}{ Erkek } & $\mathrm{n}$ & 29 & 42 & 71 & \multirow{6}{*}{1,876} & \multirow{6}{*}{0,321} \\
\hline & & $\begin{array}{l}\text { Satıra göre } \\
\text { Yüzde \% }\end{array}$ & $40,85 \%$ & $40,85 \%$ & $\begin{array}{l}100,00 \\
\%\end{array}$ & & \\
\hline & \multirow[b]{2}{*}{ Kadın } & $\mathrm{n}$ & 16 & 18 & 34 & & \\
\hline & & $\begin{array}{l}\text { Satıra göre } \\
\text { Yüzde \% }\end{array}$ & $47,06 \%$ & $52,94 \%$ & $\begin{array}{l}100,00 \\
\%\end{array}$ & & \\
\hline \multirow{2}{*}{\multicolumn{2}{|c|}{ Toplam }} & $\mathrm{n}$ & 45 & 60 & 105 & & \\
\hline & & $\begin{array}{l}\text { Satıra göre } \\
\text { Yüzde \% }\end{array}$ & $42,9 \%$ & $57,1 \%$ & $\begin{array}{l}100,00 \\
\%\end{array}$ & & \\
\hline
\end{tabular}

H5: Örgütsel bağlılık kurumdan ayrılma kararına göre farklılık gösterir

ADSM çalışanlarına uygulanan anket verilerine personelin örgütsel bağl1lığı ile kurumdan ayrılma kararları arasında farklılı̆g test etmek amac1 ile bağımsız örneklem t testi uygulanmıştır. Analiz sonuçlarına göre kurumdan ayrılmayı düşünenlerin örgütsel bağl1lık ortalaması 2,98 iken kurumdan ayrılmayı düşünmeyenlerin 3,36 olarak belirlenmiştir. Bağımsız örneklem t-testin $t=5,065$ ve buna denk gelen $\mathrm{p}=0,000<0,05$ olduğundan kurumdan ayrılmayı düşünmeyenlerin örgütsel bağlılık düzeyleri, ayrılmayı düşünenlerden daha fazladır.H5 kabul edilmiştir. Bağl1lığın ortaya çıkabilmesi için örgütten ayrılmanın maliyeti, örgütte kalmanın maliyetinden daha yüksek olmalıdır (Samadov, 2006:75-78). Literatürde örgütsel bağl1lık ve kurumdan ayrılma niyeti ilişkisini saptamaya yönelik çalışma sonuçları farklılık göstermektedir. Örneğin Tayvan'da yapılan hastanede çalışan 
Dokuz Eylül Üniversitesi İktisadi ve İdari Bilimler Fakültesi Dergisi Cilt:32, Sayl:2, Yll:2017, ss. 239-261

hemşireler üzerinde yapılan bir araştırmada, düşük örgütsel bağl1lık düzeyine rağmen kurumdan ayrılma eğilimlerinin düşük olduğu saptanmıştır (Liou and Cheng, 2010). Bu sonuç iş bulma imkânlarının zorluluğunun kurumdan ayrılmayı güçleştirdiği şeklinde yorumlanabilir. Çalışanları işte tutma konusunda şüphesiz en büyük beceri ve/veya sorumluluk yöneticilere ait olacaktır. Nitekim Afyonkarahisar Devlet Hastanesi’nde farklı unvanlara sahip toplam 321 sağlık çalışanı üzerinde yapılan bir araştırmada örgütsel bağl11ık düzeyinin artırılması için etkin ve katılımcı liderlere ve başarılı bir liderlik davranışına olan gereksinim ortaya konulmuştur. Buna göre başarılı bir lider örgüt üyelerinin örgütte kalma ve başarma arzularını artırıcı etki yapabilecektir (Karahan, 2008: 160).

\section{SONUÇ}

Sağlık işletmelerinde çalışanların kuruma olan bağl1lıkları sunulan sağlık hizmetinin etkilemektedir. Bu etkilenme hem hasta/hasta yakınlarını hem de kurum yönetimini açısından olumsuz sonuçlar doğurabilmektedir. Kurum yönetimleri çalışanların kuruma bağlılıklarını artırmak ve çalışanların kurumdan ayrılmalarını önlemek amacıyla çeşitli yöntemler geliştirmelidir. Bu çalışmada, çalışanların örgütsel bağlılık düzeylerinin cinsiyete ve eğitim durumuna göre farkl1lık göstermediği, duygusal, devam ve normatif bağlılık faktörleri arasında istatistiksel olarak anlamlı bir ilişkinin olduğu, çalışanların kurumdan ayrılma kararlarının dağılımının cinsiyete göre farklılık göstermediği ve çalışanlarının örgütsel bağlılık düzeylerinin arttığında, kurumdan ayrılma kararı kararlarında azalma meydana geldiği saptanmıştır. Örgütsel bağl1lık düzeyinin artması kurumdan ayrılma kararını etkileyen önemli bir değişken olduğu göz önüne alındığında, sağlık kurumları yöneticilerinin, çalışanların örgütsel bağlılık düzeylerini arttırıcı politikalar izlemesi önem arz etmektedir. Bu çalışma İzmir ilinde bulunan bir ADSM'nde yapılan lokal bir çalışmadır. Konu ile ilgili gelecekte yapılacak çalışmaların farklı sağlık çalışanları ve sağlık kurumlarını kapsayan, daha geniş evren ve örneklemde yapılması tarafimızdan önerilmektedir. 


\section{S.AKÇA -N.DEVEBAKAN}

\section{KAYNAKÇA}

ARGYRIS, C. (1998). Empowerment: The Emperor's New Clothes, Harvard Business Review, May-June, 98-105

AL-HUSSAMİ, M (2008). “A Study of Nurses' Job Satisfaction: The Relationship to Organizational Commitment, Perceived Organizational Support, Transactional Leadership, Transformational Leadership, and Level of Education”, European Journal of Scientific Research, 22(2): 286-295.

ALLEN, N. J., MEYER, J. P. (1990). "Organizational Commitment: Evidence of Career Stage Effects", Journal of Business Research, 26, 1, 46-91.

BALAY, R (2000). Yönetici ve Öğretmenlerde Örgütsel Bağl1lı, Nobel Yayın Dağıtım, Ankara.

BAYSAL, A. C; PAKSOY, M (1999). "Mesleğe ve Örgüte bağl1lı̆̆ın Çok Yönlü İncelenmesinde Meyer - Allen Modeli”, İ.Ü. İşletme Fakültesi Dergisi, 28(1), $7-15$.

BECKER, T. E; BİLLINGS, R. S; EVELETH, O. M; GILLBERT, N. L. (1996). "Foci and Bases of Employee Commitment: Implications for Job Performance", Academy of Management Journal, 39(2), 464-482.

BENLİGİRAY, S ; SÖNMEZ, H (2011). "Hemşirelerin Mesleki Bağl11ıkları ile Diğer Bağl11ık Formları Arasındaki İlişki: Örgüte Bağl1lık, İşe Bağlılık ve Aileye Bağlılık", Hacettepe Üniversitesi Sağlık Bilimleri Fakültesi Hemşirelik Dergisi, 28-40. 
Dokuz Eylül Üniversitesi İktisadi ve İdari Bilimler Fakültesi Dergisi Cilt:32, Sayı:2, Yıl:2017, ss. 239-261

ÇAKAR, N; DEMIRCAN, A.C (2005). "İş Motivasyonunun Çalışan Bağlılığ1 ve İşten Ayrılma Eğilimi Üzerindeki Etkileri”, Doğuş Üniversitesi S.B.E. Dergisi, 6(1): 52-66.

ÇELEN, Ö; TEKE, A; CIHANGIROĞLU, N. (2013). “Örgütsel Bağglılığın İş Tatmini Üzerine Etkisi: Gülhane Askeri Tıp Fakültesi Eğitim Hastanesinde Bir Araştırma”, Süleyman Demirel Üniversitesi İktisadi ve İdari Bilimler Fakültesi Dergisi, 18(3), 399-410.

ÇELIK, A; ÇAKICI; A.B; FINDIK, M (2014). "Çalışma İlişkilerinde Algılanan Adaletsizlik İle Örgütsel Bağlılık, İşe Devamsızlık ve İşten Ayrılma Niyeti Arasındaki İlişkilerin Belirlenmesine Yönelik Bir Araştırma: Sağlık Kurumları Örneği”, Kahraman Maraş Sütçü İmam Üniversitesi, İktisadi ve İdari Bilimler Fakültesi Dergisi, 4(2), 59-169.

ÇETIN, F (2011). Örgütsel Vatandaşlık Davranışlarının Açıklanmasında Örgütsel Bağl1lık, İş Tatmini, Kişilik ve Örgüt Kültürünün Rolü, Ankara Üniversitesi Sosyal Bilimler Enstitüsü, Yayınlanmamış Doktora Tezi, Ankara.

ÇETİN, M.Ö. (2004). Örgüt Kültürü ve Örgütsel Bağl1lı, Nobel Yayınları, İstanbul.

ÇETIN, M; ÇINAROĞLU, S; ŞAHIIN, B (2014). "Hekimlerin Kurumsal Bağl1lık Düzeylerini Etkileyen Faktörlerin İncelenmesi”, Atatürk Üniversitesi İktisadi ve İdari Bilimler Dergisi, Cilt: 28 (2), 1-55. 


\section{S.AKÇA -N.DEVEBAKAN}

DEMIREL, Y; ÖZ, B.F; YILDIRIM, G (2014). "Bir Üniversite Hastanesinde

Çalışan Hemşirelerin Kurumlarına Bağlılıklarının Değerlendirilmesi”, Van Tıp Dergisi, 21(2): 92-100.

DUYGULU, S; ABAAN, S (2007). “Örgütsel Bağl1lık: Çalışanların Kurumda Kalma ya da Kurumdan Ayrılma Kararının Bir Belirleyicisi”, Hacettepe Üniversitesi Hemşirelik Yüksekokulu Dergisi, 61-73.

ERDEM, R (2007). “Örgüt Kültürü Tipleri ile Örgütsel Bağlılık Arasındaki İlişki: Elazığ İl Merkezindeki Hastaneler Üzerinde Bir Çalışma”, Eskişehir Osmangazi Üniversitesi, İ̈BF Dergisi, 2(2), 63-79.

GIDER, Ö; ŞIMŞEK, G; OCAK, S; TOP, M (2011). "Hastane Organizasyonlarında Örgütsel Bağlılık ve İş Doyumunun Analizi: Hemşireler ve Tıbbi Sekreterler Üzerine Bir Araştırma”, Öneri, 9(35), 93-101.

GÜL, H; OKTAY, E; GÖKÇE, H (2008). “İş Tatmini, Stres, Örgütsel Bağl1lık, İşten Ayrılma Niyeti Ve Performans Arasındaki İlişkiler: Sağlık Sektöründe Bir Uygulama”, Akademik Bakış Dergisi, Sayı:15, 1-11.

İNCE, M; GÜL, H (2005). Örgütsel Bağlılık: Yönetimde Yeni Bir Paradigma, Çizgi Yayınları, Konya.

KARAHAN, A (2008). "Hastanelerde Liderlik ve Örgütsel Bağl1lık Arasındaki İlişkinin İncelenmesi”, Afyon Kocatepe Üniversitesi Sosyal Bilimler Dergisi, 10(1), 145-162. 
Dokuz Eylül Üniversitesi İktisadi ve İdari Bilimler Fakültesi Dergisi Cilt:32, Sayl:2, Yll:2017, ss. 239-261

KARAHAN, A (2009). "Hekimlerin Örgütsel Bağlllık ve İş Tatmini İlişkisinin İncelenmesine Yönelik Bir Araştırma: Afyon Kocatepe Üniversitesi Hastanesi Örneği”, Dumlupınar Üniversitesi Sosyal Bilimler Dergisi, Sayı:23, 421-432.

LIOU, S; CHENG, C. (2010). Organizational climate, organizational commitment and intention to leave amongst hospital nurses in Taiwan. Journal of Clinical Nursing, 19(11-12), 1635-1644.

MEYER, J. P; ALLEN, N. J. (1984). Testing the "side-bet theory" of organizational commitment: Some methodological considerations, Journal of Applied Psychology, 69, 372-378.

MEYER, J.P., ALLEN, N.J. (1991), "A Three-Component Conceptualization of Organizational Commitment", Human Resources Management Rewiew, 1, 61 89.

MEYER, J.P; ALLEN, N.J. (1997). Commitment in the workplace: Theory, research and application, Thousand Oaks, CA: Sage Publications.

O'REILlY, C. A., CHATMAN, J. ( 1986). "Organizational conlmitment and psychological attachment: The effects of compliance, identification, and internalization on prosocial behavior", Journal of Applied Psychology, 71, 492-499.

ÖZATA, M (2015). “Hastanelerde Görev Yapan Sağlık Çalışanlarının Örgütsel Bağl1lık Düzeylerinin Belirlenmesi”, Selçuk Üniversitesi Sosyal Bilimler Meslek Yüksekokulu Dergisi, 18(1), 155-166. 


\section{S.AKÇA -N.DEVEBAKAN}

ÖZUTKU, H. (2008). Örgüte Duygusal, Devamlılık ve Normatif Bağlllık ile İş Performansı Arasındaki İlişkinin İncelenmesi, İstanbul Üniversitesi İşletme Fakültesi Dergisi, 37(2),79-97.

RUSBULT, C.A., FARRELL, D., ROGERS, G; MAINOUS, A.G (2008). “Impact of Exchange Variables On Exit, Voice, Loyalty and Neglect: An Integrative Model of Responses to Decline Job Satisfaction”, Academy of Management Journal, 31(3), 599- 627.

SABUNCUĞLU, T.E. (2007), "Eğitim, Örgütsel Bağl1lık ve İşten Ayrılma Niyeti Arasındaki İlişkilerin İncelenmesi”, Ege Akademik Bakış, 7 (2), 613628.

SAMADOV, S (2006). İş Doyumu Ve Örgütsel Bağlılık, yayınlanmamış Yüksek Lisans Tezi, Dokuz Eylül Üniversitesi Sosyal Bilimler Enstitüsü, İzmir.

SERGÜL, D., KORKMAZ, F. (2008). Hemşirelerin Örgüte Bağlılı̆̆ı, İş doyumları ve İşten Ayrılma Nedenleri, C.Ü. Hemşirelik Yüksekokulu Dergisi, 12(2), 9-20.

SEVINÇ, İ; ALİ, Ş (2012).’Kamu Çalışanlarının Örgütsel Bağl1lığı: Karşılaştırmalı Bir Çalışma”, Maliye Dergisi, S:162, 266-281.

TEKINGÜNDÜZ, S., TENGILLIMOĞLU, D. (2013). "Hastane Çalışanlarının İş Tatmini, Örgütsel Bağlllık ve Örgütsel Güven Düzeylerinin Belirlenmesi”, Sayıştay Dergisi, S.91,77-103. 
Dokuz Eylül Üniversitesi İktisadi ve İdari Bilimler Fakültesi Dergisi Cilt:32, Sayl:2, Yll:2017, ss. 239-261

TETiK, S. (2012). "Sağlık Çalışanlarının Örgütsel Bağlılık Düzeylerini Belirlemeye Yönelik Bir Araştırma”, Sosyal ve Beşeri Bilimler Dergisi, 4(1), 275-286.

TOP, M. (2012). “Hekim ve Hemşirelerde Örgütsel Bağl1lık, Örgütsel Güven ve İş Doyumu Profili”, İstanbul Üniversitesi İşletme Fakültesi Dergisi, 41 (2), 258277.

UYGUÇ, N., ÇIMRIN, D .(2004). "DEÜ Araştırma ve Uygulama Hastanesi Merkez Laboratuvarı Çalışanlarının Örgüte Bağlılıklarını ve İşten Ayrılma Niyetlerini Etkileyen Faktörler”, DEÜ İ.İ.B.F Dergisi, 19(1), 91-99.

WAHN, J. C. (1998). "Sex Differences in the Continuance Component of Organizational Commitment. Group and Organization Management", 23(3), 256-266.

WASTI, S.A .(2002). "Affective and Continuance Commitment to the Organization: Test of an Integrated Model in the Turkish Context", International Journal of Intercultural Relations, 26, 525-550.

YALÇIN, A., İPLİK, F.N.(2005). "Beş Yıldızlı Otellerde Çalışanların Demografik Özellikleri İle Örgütsel Bağlılıkları Arasındaki İlişkiyi Belirlemeye Yönelik Bir Araştırma: Adana İli Örneği”, Çukurova Üniversitesi. S.B.E. Dergisi/E-Dergi, 14(1), 395-412.

YAVUZ, B., EZIK, S., GÜRAKAN, G. (2014). “Acil Servislerde Hasta Bakım ve Tedavi Hizmeti Veren Sağlık Çalışanlarının Örgütsel Bağlılık Düzeyleri”, Tepecik Eğitim Hastanesi Dergisi, 24 (2), 111-118. 